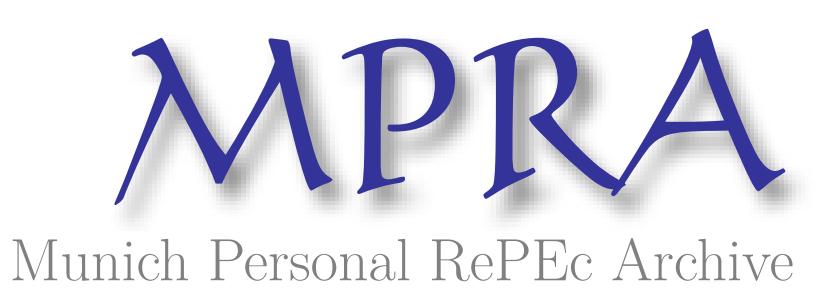

\title{
Outlook of China's State-Owned Enterprises Transformation
}

hu, yi

17 May 2012

Online at https://mpra.ub.uni-muenchen.de/43238/

MPRA Paper No. 43238, posted 13 Dec 2012 12:08 UTC 
Transformation of China's state-owned enterprises(SOEs) have been lasted for over 30 years since the beginning of China's reform In 1978.SOEs makes great success accompanied by growth of China's economy. The mainstream view about SOEs is that most policymakers and scholars wish construct a socialist market system which embedded in public ownership. The system not only uses market to efficiently allocate resources but also uses macro-control to protect mass interest and avoid intensification of wealth. However, New Institutional Economist Eric Brousseau (2008) insists that because of high transaction cost 'Privatization was assigned top-priority within most reform packages for developing and transition economies'. My research proposal creates a new historical institutional analysis framework to analyze the problem.

\section{Description of research agenda}

Transformation of China's SOEs can be defined as institution change without technology innovation, Hence the research agenda rises: when the structure of SOEs should be changed? What sequence should be followed about the priority of China's SOEs transformation within reform package? What factors contribute to evolvement of SOEs? transaction cost is a relative static concept,Foundation of evolutionary economic is thought that "novelty---replication---retention".Both of them is inappropriate to explain the transformation of China's SOEs .As far as logistical positivism is concerned,"such accounts usually rest on a model of causality that requires the assumption of unit homogeneity" Daniel Ziblatt(2010) Historian need deal with heterogeneous facts.

\section{Methodology foundation:}

The highlight of my proposal is creation of new historical institutional analysis framework .It is original without prior research. Stimulated by work of professor Maria Cristina Marcuzzo (2008), 'the most important of rational reconstructions consists in the reformulation of the arguments of past authors into a modern theoretical framework '.My research proposal is reconstruct thought of old Institutionalism, historical materialism, phenomenology and some soft system method to form a new framework. Gerald Midgley(1997) pointed out creative design of methods is "synthesis which is generated that allows each individual research question to be addressed a part of whole system question" In my view ,Creative design of methods is reconstruction of assumption and law to explain and predict event.Based on soft system thinking, the root definition of China's SOEs transformation is structure change which is compatible with China's economy transformation process to more efficient economy system.

Engels(1890) said "according to the materialist conception of history ,the ultimately determining element of history is production and reproduction of real life" and "the connomic situation is the basis but the various element of super structure ...also exercise their influence upon the course historical struggles and in many case preponderate in determining their form". Edmund Husser.(1954) pointed out "the 
truth is established only in the self-evidence of critical over-all view which brings to light ,behind "the historical fact" of documented philosophical theories and their apparent opposition and parallels a meaningful final having" Peter Checkland (1999) thought 'Social reality is the ever-changing outcome of the social process in which human beings ,the product of their genetic inheritance and previous experience, continually negotiate and re-negotiate with others their perceptions and interpretation of world outside themselves'. historical materialism, phenomenology and soft system methodology constitutes the philosophy basis of my new method. Hence the framework is comprised of three parts below.

1) Reduction of conviction and motivation inside typical case which based on 'Behavior Subject' is deemed as inducing factors of system change. According to actor-system-dynamics theory, "'actor, individual and collective agents---in their various positions embedded in complex structure"Tom R.Burns(2006) 'Behavior subject' is a new Multi-actor assumption. Michael C. Jakson (2003) also said that 'We now have six elements that a root definition make reference,...W="world view" makes transformation meaningful'.

2) System change will be ultimately beneficial to the efficiently allocation of resources. Concept of Adaptive Efficiency is reconstructed in micro and macro lever

1) Typical case

\section{Simple upholding to prove the rationality and contractibility of}

\section{the framework}

There is a typical economic factor in China's economy that the amount of deposits over loans reached 13 trillion yuan, which is the source of liquidity. According to the analysis of Keynes, the motivation of deposits is due to the prudent motive and investment motive. The factor shows our social security system is not good enough to meet people's requirement, people lack investment channels. It results in a large number of deposits. We have to reduce state-owned shares to enrich the social security fund, give more investment opportunities to private capital.Now we have come to conclusion that changing economic growth mode must rely on independent innovation. According to thought of Joseph Schumpeter, entrepreneurs is the main organizer of economic development, which is a new combinational factors of production and innovation.Innovation of entrepreneurs also has motives of obtaining ownership, In order to stimulate innovation, We have to reduce some state-owned shares to entrepreneurs .Based on our concept of successful reform ----two-track system, the core thought of two-track system is that let new market factor gradually play the role meanwile maintaing the operation of the old scheme until new market factor ultimately replaced the old scheme. Our successful reform of price is a good example .Our state-owned enterprise reform should be similar to price reform, From the protection of private property into the 
Constitution to support of non-public-owned enterprises development, we have gradually play the role of non-public enterprises. That means non-public-owned enterprises would replace state-owned enterprises.

Time that non-public-owned enterprises replace state-owned enterprises.is decided by whether it is beneficial to the efficiently allocation of resources.(1) Chinese state-owned enterprises Transformation will minimize the negative effects of the asset bubble ," Reducing state-owned share not only benefits social security system to stimulate demand but also absorbs invest demand in real estate market." Yi Hu.(2011).

(2) From a sustainable development perspective, It is not rational that economic growth relys on investment for the investment rate reaching $50 \%$. Also because the United States secondary debt crisis is spreading, it is not realistic to rely heavily on exports to boost economic growth, we have to speed up the building of the social security system to stimulate consumption growth, and stimulate innovation to achieve sustainable growth. (3) Since the introduction of independent directors,we have use up all company internal control approach. We have to let enterprise free market price, improve low operating efficiency by freedom of mergers and bankruptcy. This also require reduction of state-owned shares. (4) For the good quality of state-owned enterprise assets, there is someone who object reform of state-owned enterprises, we have to point out that many state-owned enterprises rely on the scale effect and its monopoly position to maintain their own dominance, In fact,in some competitive field of advanced productive forces private enterprises have made great progress and obtain dominance. such as Huawei and Sina, however state-owned enterprises dispeared (5) Mr. Deng Xiaoping pointed out that "Let market play basic role in resource allocation ".To accelerate the reform of state-owned enterprises, we must implement this ideology

\section{Conclusion}

Prevaricating SOE is unavoidable but priority is not the top. Efficient allocation of resources is the ultimate goal of economy system. My research is helpful for transformation of economy system which is in planned economy, It also enhance undemanding the evolvement of economy system.

Ref

Edmund Husser.(1954) Crisis of European Sciences and Transcendental Phenomenology. Northwestern University Press, 1970

Eric Brousseau and Jean-Michel Glachat(2008). New Institutional Economics a Guidebook .Cambridage University Press.

Gerald Midgley .(1997) .Developing the Methodology of TSI: from the Obligue use of Methods to Creative Design. System Practice ,Vol.10 NO.3,1997

Giovanni Capoccia and Daniel Ziblatt .(2010).The historical Turn in Democratization 
Studies: A New Research Agenda for Europe and Beyond. Comparative Political Studies 2010 43-931

Michael C. Jackson (2003) Systems Thinking: Creative Holism for managers.John Wiley \& Son Ltd

Maria Cristina Marcuzzo (2008) Is History of Economic Thought a "serious" subject? Journal for Philosophy and Economics, Volume 1, Issue 1,Autumn 2008, pp. $\mathrm{XX}-\mathrm{XX}$.

Peter Checkland (1999).Soft System Methodology a 30-year retrospecfive.John Wiiley \& SONS LTD

TOM R.BURNS. (2006). THE SOCIOLOGY OF COMPLEX SYSTEMS :AN OVERVIEW OF ACTOR-SYSTEM-DYNAMICS THEORY .World Future,62:411-440,2006 Yi hu(2011).NALYSIS OF CHINA'S ECONOMY SYSTEM FAILURE http://journals.isss.org/index.php/proceedings55th/article/view/1609,ISSN 19996918. 